\title{
CURRENT THERAPEUTIC EVIDENCE BASED APPROACHES TO PATIENTS WITH FALCIPARUM AND NON-FALCIPARUM MALARIA
}

\section{A.S. Sydorchuk, V.D. Moskaliuk}

HSEE of Ukraine «Bukovinian State Medical University», Chernivtsi

Key words: treatment, Plasmodium, relapse, severe malaria.

Clinical and experimental pathology 2020. Vol.19, №3 (73). P.202-207.

DOI: $10.24061 / 1727-4338$ XIX.3.73.2020.28

E-mail: sidorchuk@bsmu.edu.ua

Malaria is a major concern for international health authorities and potentially lifethreatening disease because of millions of people suffer every year in the world due to a parasite of the Plasmodium genus transmitted by an infective female Anopheles mosquito vector. Due to the complexity of the parasite biology and genetics, there is currently no vaccine. Individuals with malaria may present with fever and a wide range of symptoms. The second half of the 20th century saw the emergence of strains of malaria parasites (mainly P.falciparum) resistant to chloroquine, which was the most commonly used drug for treatment of the disease. While resistance spread geographically, it also evolved chemically including to other antimalarial drugs like quinine, sulfadoxine, pyremethamine, and proguanil.

The aim of research. To describe modern aspects of etiology and epidemiology of malaria, caused by different species of parasite; and to highlight clinical peculiarities with analysis of the best evidence based recommendations of its chemotherapy.

Methods. We had used scientific paper searching in Scopus, Cochrane databases, and NCBI library (Pubmed) by key words as "malignant tertian malaria treatment", "benign tertian malaria", benign quartana malaria”, "malaria and pregnancy", "resistance to antimalarials".

Results. Nowadays there are six known genetically different species of Plasmodium caused malaria disease in human worldwide. This vector-borne infection may transmit via mosquito, blood products, a liver transplantation and through placenta from pregnant to fetus. If suspected any malaria type, promptly therapy should be suggest accounted travel anamnesis and WHO as well as national recommendations. Therapy contained arthemisin in combination with lumefantrine or mefloquine is better and more effective than monotherapy. In case of P.ovale and P.vivax primaquine phosphate is essential to preclude recrudescences.

Conclusions. Ukraine is the eastern European country with annual morbidity because of exotic cases connected with travels and employment. In case of fever, chills, sweats, hepatosplenomegaly patient should be tested for parasite presence by methods of parasitoscopy of thick drop and thin smear of blood. Chemoprophylaxis within all duration in endemic country by available antimalarial should be obligatory before planning to subtropical and tropical regions.

\section{Ключові слова: \\ лікування, плазмодій, реичицв, тяжка ма- лярія.}

Клінічна та експериментальна патологія 2020. T.19, №3(73). C.202-207.

\section{СУЧАСНІ ПІДХОДИ ДО ЛІКУВАННЯ РІЗНИХ ВИДІВ МАЛЯРІЇ 3 УРАХУВАННЯМ ЗАСАД ДОКАЗОВОЇ ІНФЕКТОЛОГЇ}

\section{А.С. Сидорчук, В.Д. Москалюк}

Малярія викликає велике занепокоєння міжнародних інстанцій охорони здоров'я та є потениійно небезпечною для життя хворобою мільйонів людей, які щзороку страждають у світі через иьього збудника - паразита роду плазмодії, які передаються самкою комара роду Anopheles. Через складну біологію і генетику паразита, на даний час вакиини не існує. Хворі на малярію можуть мати лихоманку та широкий спектр симптомів. У другій половині ХХ століття з'явилися штами паразитів малярії (переважно P. falciparum), які є стійкі до хлорохіну, щзо найчастіше використовувся для лікування захворювання. Резистентність поширилася географічно, однак вона також «еволючіонувала хімічно», охопивии інші протималярійні препарати, такі як хінін, сульфадоксин, піреметамін та прогуаніл.

Мета дослідження. Проаналізувати сучасні аспекти хіміотерапї малярії з огляду на тип плазмодія, його географічний нозоареал, вікові та гендерні особливості, клінічний перебіг та лабораторні показники з урахуванням міжнародних рекомендацій в ухваленні правильних клінічних рімень.

Матеріал і методи. Проведено огляд релевантних наукових публікацій баз даних Scopus, Cochrane ma бібліотеки NCBI (Pubmed) за такими ключовими словами: «лікування злоякісної третинної малярії», «доброякісна третинна малярія», доброякісна чотириденна малярія». 
Результати. На сьогоднішній день у світі відомо шість генетично різних видів плазмодія, які здатні спричинити хворобу в людини. Ця трансмісивна інфекція може передаватися через укус комара, через препарати інфікованої крові, трансплантацію печінки та через плаценту від вагітної до плоду та новонародженого. Якщзо підозрюється будь-який тип малярії, слід негайно запропонувати терапію з урахуванням анамнезу подорожей, рекомендацій ВООЗ та національних рекомендащій. Терапія, щз містить артемізин у комбінації $з$ люмефантрином або мефлохіном є кращзою та ефективнішою за монотерапію. $У$ випадку малярії, спричиненої Р. оvale та Р.vivax призначення примахіну фосфату $\epsilon$ необхідним, оскільки запобігає ймовірності рецидивів.

Висновки. Украӥна є східноєвропейською краӥною з щорічною захворюваністю через завізні випадки, пов'язані з поїзками та працевлаштуванням. У разі лихоманки, ознобу, поту, гепатоспленомегалії пацієнт повинен бути перевірений на наявність паразитів методами мікроскопї̈ товстої краплі та тонкого мазка крові. Хіміпрофілактика доступними антималярійними препаратами повинна бути обов'язковою перед плануванням візиту, упродовж усього періоду перебування в ендемічній країні та місяияь після повернення із субтропічних та тропічних регіонів.

\section{СОВРЕМЕННЫЕ ПОДХОДЫ К ЛЕЧЕНИЮ РАЗЛИЧНЫХ ВИДОВ МАЛЯРИИ С УЧЕТОМ ОСНОВ ДОКАЗАТЕЛЬНОЙ ИНФЕКТОЛОГИИ}

\section{А.С. Сидорчук, В.Д. Москалюк}

Малярия вызывает большое беспокойство международных инстанциий здравоохранения и является потенциально опасной для жизни болезнью миллионов людей, которые ежегодно страдают в мире из-за этого возбудителя - паразита рода плазмодиев, которые передаются самкой комара рода Anopheles. Из-за сложной биологии и генетики паразита, на данное время вакцинь не существует. Больные малярией могут иметь лихорадку и иирокий спектр симптомов. Во второй половине ХХ века появились итаммы паразитов малярии (в большинстве P.falciparum), которые являются стойкими к хлорохину, что чаще всего используется для лечения заболевания. Резистентность распространилась географически, но она также «эволючионировала химически», охватив другие противомалярийные препараты, такие как хинин, сульфодоксин, пиреметамин и прогуанил.

Цель исследования. Проанализировать современные аспекты химиотерапии малярии с учетом типа плазмодия, его географического нозоареала, возрастных и гендерных особенностей, клиническое течение и лабораторные показатели и с учетом международных рекомендаций в принятии правильных клинических ремений.

Материал и методы. Проведён обзор релевантных научных публикаций баз данных Scopus, Cochrane и библиотеки NCBI (Pubmed) со следующими ключевьли словами: «лечение злокачественной третичной малярии», «доброкачественная третичная малярия», доброкачественная малярия».

Результаты. На сегодняшний день в мире известно шесть генетически различных видов плазмодия, которые могут вызвать болезнь у человека. Эта трансмиссивная инфекиия может передаваться через укус комара, через препараты инфицированной крови, трансплантацию печени и через плаценту от беременной к плоду и новородженому. Если подозревается любой тип малярии, стоит немедленно предложить терапию с учетом анамнеза путешествий, рекомендаџий ВООЗ и наџииональных рекомендаций. Терапия, состоящая из артемизина в комбинации с люмефантрином или мефлохином является лучшей и более эффективной чем монотерапия. В случае малярии, вызываемой Р.оvale u Р.vivax назначение примахина фосфата является необходимым, поскольку предупреждает возможность рецидивов.

Выводы. Украина является восточно-европейской страной с ежегодной заболеваемостью из-за завезенных случаев, связаных с поездками и трудоустройством. В случае лихорадки, озноба, пота, гепатоспленомегалии пациент должен быть проверен на наличие паразитов методами микроскопии толстой капли и тонкого мазка крови. Химиопрофилактика доступнылми антималярийными препаратами должна быть обязательной перед планированием визита, во время всего периода пребывания в эндемической стране и месяия после

\section{Ключевые слова:} лечение, плазмодии, рециидив, тяжелая малярия.

Клиническая и экспериментальная патология 2020. T.19, №3 (73). C.202-207. 


\section{Introduction}

Malaria is undoubtedly remains a scourge of mankind from very ancient times. Evolutionary biologists suggest that Plasmodium parasite was causing human disease for the last 100,000 years. Malaria now is still ranked the third leading cause of death due to an infectious agent after HIV and tuberculosis [1].

By WHO report, there are 219 milions of malaria cases in the world and 435000 deaths at the end of 2017 [2]. Totally, the risk to have malaria have 3.3 miliard of Earth population, moreover, for third part of them risk are very high because they live in countries with annual morbidity around thousand people [3].

Notably, that now the list of endemic malaria countries consist of 91 now in comparison with 87 five years ago, perhaps due to climate changes. Spreading and morbidity of malaria depend on unique insect - a vector of Plasmodium parasite - female mosquito of Anopheles genus. Nevertheless, social and economic development of country, free access for medical care and poverty of population are also factors of crucial importance [2].

Malaria is a transmissive parasitic infectious disease that is characterized by periodical fever paroxysms, liver and spleen enlargement, hemolytic anemia and jaundice. In human host it caused by six plasmodium types: $\mathrm{P}$. vivax, P. malariae, P.ovale, P. falciparum and P. knowlesi and less known and geographically restricted P. simium. Tropical malaria is caused by Plasmodium falciparum parasite, which is the most severe one with high risk of cerebral malaria development and correlated with it the highest lethality. Such parasites as Plasmodium vivax and Plasmodium ovale are able to persist in the human host up to three years and then as dormant forms in the liver may reactivate and lead to early or late relapses.

In Europe, malaria was endemic till 1970. Recent Annual report of European Center for Disease Control (ECDC) report about 8349 cases in 2018, and 99,8\% of them are travel-related cases. Malaria season in a few European countries like Italy, France, Spain and Greece lasted from July to September. Interestingly, that the overall rate of confirmed malaria cases was higher among men than women (1.6 cases and 0.7 cases per 100000 population, respectively; male-to-female ratio 1.9:1) [4].

In Ukraine, most cases of malaria are exotic, and occurred after travelling to endemic Asian and African countries in people who did not follow preventive chemoprophylaxis there within all the time of being in zone of malaria spreading.

Annually, in Ukraine there were up to 50 cases of disease, and near tenth part of them, unfortunately, with fatal outcome. All cases connected with touristic trips and, rare - in foreign students from endemic countries [5].

\section{Results}

Current review of modern scientific papers about malaria in Ukraine had evidenced few important conclusions from both epidemiologic and clinical points of view. Moderate and severe malaria mainly occurred ISSN 1727-4338 https://www.bsmu.edu.ua within two weeks (maximum - 47 days) upon arrival from endemic country. Tropical malaria has polymorphic clinical presentation, that's why physicians should be more attentive when questioning in details epidemic and occupational anamnesis (cases in geologists, sailors, aircraft staff, military staff). It's nesessary to understand, that the diagnosis may be missed if a history of travel is not elicited.

Infected typically present with non-specific symptoms such as fever, chills, sweats, headache, and myalgia. Differential diagnosis due to these non specific symptoms include leptospirosis, influenza, viral hepatitis, yellow fever etc. It should be remembered that clinical symptoms of malaria in country with moderate climate as Ukraine can appear in any time because this disease is mainly travel related tropical illness. Examination of a Giemsa-stained blood film remains the diagnostic test of choice and should be repeated few times. Once the diagnosis of malaria is confirmed, treatment should be started urgently, as a delay may be associated with disease progression, complications and death.

Infection may also occur through infected blood transfusion [6-8]. Cases of vertical transmission are also happened especially in hyperendemic countries.

The geographical distribution of parasite species is dependent on ecological and social, behavioral factors affecting the ability of mosquitoes to transmit Plasmodium [9].

$\sqrt{ } \mathrm{P}$ falciparum is widespread in the tropic zones of Sub-Saharan Africa, areas of Southeast Asia, Oceania, and the Amazon basin of South America [1].

$\sqrt{ } \quad \mathrm{P}$ vivax is predominantly found in most of Asia, the Americas, parts of Eastern Europe, and North Africa [10]. Nevertheless, about $80 \%$ of all cases occur in Ethiopia, India, and Pakistan. If compare these two parasites, $\mathrm{P}$ vivax has a much wider distribution, as it can develop in the insect at lower temperatures and cooler climates. Both with $\mathrm{P}$ ovale, it has a dormant liver stage and can reactivate within 3 years, causing a late relapse.

$\sqrt{ } \quad \mathrm{P}$ ovale is occurring primarily in central and western Africa and islands in the West Pacific [11].

$\sqrt{ } \quad \mathrm{P}$ malariae has a same distribution like $\mathrm{P}$ falciparum but a lower prevalence [12-13].

$\sqrt{ } \mathrm{P}$ knowlesi is spread in certain forested areas of Southeast Asia.

$\sqrt{ }$ P. simium is spread in the Rio-de-Janeiro territory, genetically is different from the rest species, can cause malaria in human.

Treatment will depend on the infecting species, the appearance of the blood smear (\% parasitaemia, presence of pre-schizonts or schizonts), and the clinical status of the patient. Consideration should be given to the likely susceptibility of the parasite to the treatment used, based on known epidemiology relating to the geographical area where the infection was acquired. Consequently, the goal of therapy is to eradicate infection; to reduce the risk of complications by reducing the parasite burden as soon as possible; and to avoid selecting resistance by using multiple agents.

Клінічна та експериментальна патологія. 2020. Т.19, № 3 (73) 
Severity of $\mathrm{P}$ falciparum malaria is explained by sequestration, rosetting, impaired red cell deformability, cytokine responses, and high levels of parasitaemia [5].

Plasmodium falciparum malaria is potentially fatal if not treated immediately, because life-threatening complications can develop rapidly in patients who initially appear well, and even short delays increase mortality risk [5].

Clinical and laboratory findings of severe malaria, caused by $\mathrm{P}$. falciparum. Patients are considered as having severe malaria if they have one or more next features [15]. Clinical features: impaired consciousness (i.e., Glasgow coma score $<11$ in adults or Blantyre coma score $<3$ in children); clinical signs of jaundice; multiple convulsions (more than 2 episodes in 24 hours); prostration (generalised weakness so that the patient is unable to walk or sit up without assistance); significant bleeding (recurrent or prolonged bleeding from nose, gums, venepuncture sites, haematemesis, melaena); deep breathing, respiratory distress (acidotic breathing); pulmonary oedema (radiological finding, or oxygen saturation $<92 \%$ on room air with a respiratory rate $>30$ breaths/minute often with crepitations on auscultation); circulatory collapse or shock - systolic blood pressure $<80 \mathrm{mmHg}$ in adults and $<70 \mathrm{mmHg}$ in children (decompensated shock); capillary refill $\geq 3$ seconds or temperature gradient on leg (mid-to-proximal limb) without hypotension (compensated shock).

Laboratory features: hyperparasitaemia (from above $2 \%$ to $>10 \%$ ); hypoglycaemia (blood glucose $<40 \mathrm{mg}$ / $\mathrm{dL}[<2.2 \mathrm{mmol} / \mathrm{L}]$ ); serum bilirubin $>3 \mathrm{mg} / \mathrm{dL}[>50$ micromol/L] with a parasite count $>100,000 /$ microlitre; renal impairment (serum creatinine $>3 \mathrm{mg} / \mathrm{dL}[265$ micromol/L]); metabolic acidosis (plasma bicarbonate $<15 \mathrm{mEq} / \mathrm{L}[<15 \mathrm{mmol} / \mathrm{L}]$ ); severe malarial anaemia (children $<12$ years of age: $\mathrm{Hb} \leq 5 \mathrm{~g} / \mathrm{dL}$ or haematocrit of $\leq 15 \%$; adults: $\mathrm{Hb}<7 \mathrm{~g} / \mathrm{dL}$ or haematocrit of $<20 \%$ ) with a parasite count $>10,000 /$ microliter.

In non-immune patients (travelers from European countries) and people in low-transmission settings, parasitaemia above $2 \%$ is associated with increased risk of severe disease [13].

Supportive therapy is essential and vital with purpose of correcting the all above-mentioned complications. This includes correct fluid management, often with renal support; breathe support, control of convulsions, and transfusion of blood products. Hypoglycaemia as one of significant laboratory findings of severe disease may be worsened by quinine-induced hyperinsulinaemia [14].

Recommended therapeutic scheme for severe falciparum infection is:

artesunate (parenteral) should be given until the patient is able to take oral treatment (at least 24 hours) and parasitaemia has fallen to less $1 \%$ (usually a minimum of three doses), followed by one of the following oral schemes: a full course of locally available ACT; atovaquone/proguanil; doxycycline or clindamycin, with or without quinine; or mefloquine $[15,16]$.

The WHO recommends alternative regimen like intramuscular artemether (preferly than quinine) if parenteral artesunate is not available. Also, a single dose of rectal artesunate may be administered to children less 6 years of age [17]. A Cochrane review found that artemether is more effective than quinine in children and adults with severe malaria, and is less effective to artesunate in adults [18].

Therapeutic scheme to non-falciparum malaria infection. P. malariae, P. vivax, P. ovale, or P. knowlesi infection should be treated with oral chloroquine (preferred) or oral hydroxychloroquine for a total of three doses. P knowlesi, which is found in parts of Southeast Asia, replicates every 24 hours, therefore, quick diagnostics and correct treatment of parasitic infection is essential [19]. P. vivax and P. ovale therapy schemes should be followed by oral primaquine for 14 days to eliminate the hypnozoite stages that are dormant in the liver tissue. The hypnozoiticidal activity of primaquine is predominantly a function of the total administered dose. The WHO recognises that a higher dose is needed in Southeast Asia, where there is a higher rate of relapse than in other areas [20]. Alternative schemes have been suggested (a shorter seven-day course, once-weekly dosing) to improve patient compliance $[21,22]$.

\section{Conclusions}

Essential to understand, that uncontrolled selftreatment during stay in endemic areas can lead to long lasted persistence and late relapses [23]. There are often occur more severe cases of Falciparum malaria among military staff of Caucasian race, as in the study were described about Ukrainian soldiers after mission in Liberia. The most effective in treatment was scheme that include arthemeter parenteral $\left(1^{\text {st }}\right.$ day $160 \mathrm{mg}$, next four days $-80 \mathrm{mg}$, plus doxycycline $100 \mathrm{mg}$ twice a day followed by fansidar three pills at once [24]. In endemic and hyperendemic areas the administration of primaquine is precluding $\mathrm{P}$. falciparum transmission and is suggested for travelers of a long stay there [25].

\section{Список літератури}

1. Snow RW, Guerra CA, Noor AM, Noor AM, Myint HY, Hay SI. The global distribution of clinical episodes of Plasmodium falciparum malaria. Nature. 2005;434(7030):214-7. doi: 10.1038/ nature 03342

2. World Health Organization. World malaria report 2017 [Internet]. Geneva: WHO; 2017[cited 2020 Oct 16]. 160 p. Available from: https://www.who.int/docs/default-source/documents/worldmalaria-report-2017.pdf?sfvrsn $=8 \mathrm{~b} 7 \mathrm{~b} 573 \mathrm{a} \_0$

3. Meunier YA. Tropical diseases: a practical guide for medical practitioners and students. N Y: Oxford University Press; 2014, p. 7-15. doi: 10.1093/med/9780199997909.001.0001

4. European Center for Disease Prevention and Control. Malaria. Annual Epidemiological Report for 2018 [Internet]. Annual Epidemiological Report on Communicable Diseases in Europe. 2019 [cited 2020 Oct 16]. 6 p. Available from: https://www. ecdc.europa.eu/sites/default/files/documents/malaria-annualepidemiological-report-2018.pdf

5. Малярія [Інтернет]. Київ: Центр громадського здоров'я МО3 України; 2020[цитовано Жов 16]. Доступно: https://www.phc. org.ua/kontrol-zakhvoryuvan/inshi-infekciyni-zakhvoryuvannya/ malyariya

6. Isaacson M. Airport malaria: a review. Bull World Health Organ. 1989;67(6):737-43.

7. Evans RJ. Nosocomial malaria. Lancet. 1997;349(9051):574. doi: 
https://doi.org/10.1016/S0140-6736(05)64339-5

8. Moro ML, Romi R, Severini C, Casadio GC, Sarta G, Tampieri $\mathrm{G}$, et al. Patient-to-patient transmission of nosocomial malaria in Italy. Infect Control Hosp Epidemiol. 2002;23(6):338-41. doi: $10.1086 / 502062$

9. Mendis K, Sina BJ, Marchesini P, Carter R. The neglected burden of Plasmodium vivax malaria. Am J T rop Med Hyg. 2001;64(1-2 Suppl):97-106. doi: 10.4269/ajtmh.2001.64.97

10. Collins WE, Jeffery GM. Plasmodium ovale: parasite and disease. Clin Microbiol Rev. 2005;18(3):570-81. doi: 10.1128/ CMR.18.3.570-581.2005

11. Mueller I, Zimmerman PA, Reeder JC. Plasmodium malariae and Plasmodium ovale - the "bashful" malaria parasites. Trends Parasitol. 2007;23(6):278-83. doi: 10.1016/j.pt.2007.04.009

12. Collins WE, Jeffery GM. Plasmodium malariae: parasite and disease. Clin Microbiol Rev. 2007;20(4):579-92. doi: 10.1128/ CMR.00027-07

13. World Health Organization. Guidelines for the treatment of malaria [Internet]. 3rd ed. Geneva: WHO; 2015[cited 2020 Oct16]. 316 p. Available from: https://www.who.int/docs/ default-source/documents/publications/gmp/guidelines-for-thetreatment-of-malaria-eng.pdf

14. Centers for Disease Control and Prevention. Treatment of malaria: guidelines for clinicians (United States). Part 2: general approach to treatment and treatment of uncomplicated malaria [Internet]. 2019[cited 2020 Oct 16]. 8 p. Available from: https://www.cdc. gov/malaria/resources/pdf/clinicalguidance.pdf

15. Moore DA, Jennings RM, Doherty TF, Lockwood DN, Chiodini PL, Wright SG, et al. Assessing the severity of malaria. BMJ. 2003;326(7393):808-9. doi: 10.1136/bmj.326.7393.808

16. Toovey S. Effectiveness of co-artemether in an unsupervised outpatient setting for the treatment of falciparum malaria. Travel Med Infect Dis. 2008;6(1-2):29-31. doi: 10.1016/j. tmaid.2007.08.007

17. World Health Organization. Rectal artesunate for pre-referral treatment of severe malaria [Internet]. WHO; 2017[updated 2018 Oct; cited 2020 Oct 16]. 8 p. Available from: https://apps.who.int/ iris/bitstream/handle/10665/259356/WHO-HTM-GMP-2017.19eng.pdf?sequence $=1$

18. Esu EB, Effa EE, Opie ON, Meremikwu MM. Artemether for severe malaria. Cochrane Database Syst Rev [Internet]. 2019 [cited 2020 Oct 16];2019(6):CD010678. Available from: https:/www.ncbi.nlm.nih.gov/pmc/articles/PMC6580442/pdf/ CD010678.pdf doi: 10.1002/14651858.CD010678.pub3

19. Cox-Singh J, Davis TM, Lee KS, Shamsul SSG, Matusop A, Ratnam S, et al. Plasmodium knowlesi malaria in humans is widely distributed and potentially life threatening. Clin Infect Dis. 2008;46(2):165-71. doi: 10.1086/524888

20. John GK, Douglas NM, von Seidlein L, Nosten F, Baird JK, White NJ, et al. Primaquine radical cure of Plasmodium vivax: a critical review of the literature. Malar J [Internet]. 2012[cited 2020 Oct 18];(11):280. Available from: https://www.ncbi.nlm. nih.gov/pmc/articles/PMC3489597/pdf/1475-2875-11-280.pdf doi: $10.1186 / 1475-2875-11-280$

21. Milligan R, Daher A, Graves PM. Primaquine at alternative dosing schedules for preventing relapse in people with Plasmodium vivax malaria. Cochrane Database Syst Rev [Internet]. 2019[cited 2020 Oct 16];(7):CD012656. Available from: https://www.ncbi. nlm.nih.gov/pmc/articles/PMC6611223/pdf/CD012656.pdf doi: 10.1002/14651858.CD012656.pub2

22. Taylor WRJ, Thriemer K, von Seidlein L, Yuentrakul P, Assawariyathipat T, Assefa A, et al. Short-course primaquine for the radical cure of Plasmodium vivax malaria: a multicentre, randomised, placebo-controlled non-inferiority trial. Lancet.

ISSN 1727-4338 https://www.bsmu.edu.ua
2019;394(10202):929-38. doi: 10.1016/S0140-6736(19)31285-1

23. Сокол АМ, Сидорчук АС, Богачик НА, Венгловська ЯВ. Малярія vivax на Буковині: клінічний випадок безконтрольного самолікування. ScienceRise: Medical Science. 2017;(7):30-3. doi: 10.15587/2519-4798.2017.107918

24. Трихліб ВІ, Карімов I3, Кондратюк ВВ, Павловська МО, Артемов ОС, Хомякова АЮ, та ін. Аналіз важких випадків тропічної малярії. Сімейна медицина. 2013;(1):135-9.

25. Graves PM, Gelband H, Garner P. Primaquine for reducing Plasmodium falciparum transmission. Cochrane Database Syst Rev [Internet]. 2012[cited 2020 Oct 16];(9):CD008152. Available from: https://www.cochranelibrary.com/cdsr/ doi/10.1002/14651858.CD008152.pub2/epdf/full doi: 10.1002/14651858.CD008152.pub2

\section{References}

1. Snow RW, Guerra CA, Noor AM, Noor AM, Myint HY, Hay SI. The global distribution of clinical episodes of Plasmodium falciparum malaria. Nature. 2005;434(7030):214-7. doi: 10.1038/ nature 03342

2. World Health Organization. World malaria report 2017 [Internet]. Geneva: WHO; 2017[cited 2020 Oct 16]. 160 p. Available from: https://www.who.int/docs/default-source/documents/worldmalaria-report-2017.pdf?sfvrsn=8b7b573a_0

3. Meunier YA. Tropical diseases: a practical guide for medical practitioners and students. N Y: Oxford University Press; 2014, p. 7-15. doi: 10.1093/med/9780199997909.001.0001

4. European Center for Disease Prevention and Control. Malaria. Annual Epidemiological Report for 2018 [Internet]. Annual Epidemiological Report on Communicable Diseases in Europe. 2019[cited 2020 Oct 16]. 6 p. Available from: https://www. ecdc.europa.eu/sites/default/files/documents/malaria-annualepidemiological-report-2018.pdf

5. Maliariia [Malaria] [Internet]. Kiev: Tsentr hromads'koho zdorov'ia MOZ Ukrainy; 2020[tsytovano Zhov 16]. Dostupno: https://www.phc.org.ua/kontrol-zakhvoryuvan/inshi-infekciynizakhvoryuvannya/malyariya (in Ukrainian).

6. Isaacson M. Airport malaria: a review. Bull World Health Organ. 1989;67(6):737-43.

7. Evans RJ. Nosocomial malaria. Lancet. 1997;349(9051):574. doi: https://doi.org/10.1016/S0140-6736(05)64339-5

8. Moro ML, Romi R, Severini C, Casadio GC, Sarta G, Tampieri $\mathrm{G}$, et al. Patient-to-patient transmission of nosocomial malaria in Italy. Infect Control Hosp Epidemiol. 2002;23(6):338-41. doi: $10.1086 / 502062$

9. Mendis K, Sina BJ, Marchesini P, Carter R. The neglected burden of Plasmodium vivax malaria. Am J T rop Med Hyg. 2001;64(1-2 Suppl):97-106. doi: 10.4269/ajtmh.2001.64.97

10. Collins WE, Jeffery GM. Plasmodium ovale: parasite and disease. Clin Microbiol Rev. 2005;18(3):570-81. doi: 10.1128/ CMR.18.3.570-581.2005

11. Mueller I, Zimmerman PA, Reeder JC. Plasmodium malariae and Plasmodium ovale - the "bashful" malaria parasites. Trends Parasitol. 2007;23(6):278-83. doi: 10.1016/j.pt.2007.04.009

12. Collins WE, Jeffery GM. Plasmodium malariae: parasite and disease. Clin Microbiol Rev. 2007;20(4):579-92. doi: 10.1128/ CMR.00027-07

13. World Health Organization. Guidelines for the treatment of malaria [Internet]. 3rd ed. Geneva: WHO; 2015[cited 2020 Oct16]. 316 p. Available from: https://www.who.int/docs/ default-source/documents/publications/gmp/guidelines-for-the- 
treatment-of-malaria-eng.pdf

14. Centers for Disease Control and Prevention. Treatment of malaria: guidelines for clinicians (United States). Part 2: general approach to treatment and treatment of uncomplicated malaria [Internet]. 2019[cited 2020 Oct 16]. 8 p. Available from: https://www.cdc. gov/malaria/resources/pdf/clinicalguidance.pdf

15. Moore DA, Jennings RM, Doherty TF, Lockwood DN, Chiodini PL, Wright SG, et al. Assessing the severity of malaria. BMJ. 2003;326(7393):808-9. doi: 10.1136/bmj.326.7393.808

16. Toovey S. Effectiveness of co-artemether in an unsupervised outpatient setting for the treatment of falciparum malaria. Travel Med Infect Dis. 2008;6(1-2):29-31. doi: 10.1016/j. tmaid.2007.08.007

17. World Health Organization. Rectal artesunate for pre-referral treatment of severe malaria [Internet]. WHO; 2017[updated 2018 Oct; cited 2020 Oct 16]. 8 p. Available from: https://apps.who.int/ iris/bitstream/handle/10665/259356/WHO-HTM-GMP-2017.19eng.pdf?sequence $=1$

18. Esu EB, Effa EE, Opie ON, Meremikwu MM. Artemether for severe malaria. Cochrane Database Syst Rev [Internet]. 2019[cited 2020 Oct 16];2019(6):CD010678. Available from: https://www.ncbi.nlm.nih.gov/pmc/articles/PMC6580442/pdf/ CD010678.pdf doi: 10.1002/14651858.CD010678.pub3

19. Cox-Singh J, Davis TM, Lee KS, Shamsul SSG, Matusop A Ratnam S, et al. Plasmodium knowlesi malaria in humans is widely distributed and potentially life threatening. Clin Infect Dis. 2008;46(2):165-71. doi: 10.1086/524888

20. John GK, Douglas NM, von Seidlein L, Nosten F, Baird JK, White NJ, et al. Primaquine radical cure of Plasmodium vivax: a critical review of the literature. Malar J [Internet]. 2012[cited 2020 Oct 18];(11):280. Available from: https://www.ncbi.nlm. nih.gov/pmc/articles/PMC3489597/pdf/1475-2875-11-280.pdf doi: $10.1186 / 1475-2875-11-280$

21. Milligan R, Daher A, Graves PM. Primaquine at alternative dosing schedules for preventing relapse in people with Plasmodium vivax malaria. Cochrane Database Syst Rev [Internet]. 2019[cited 2020 Oct 16];(7):CD012656. Available from: https://www.ncbi. nlm.nih.gov/pmc/articles/PMC6611223/pdf/CD012656.pdf doi: 10.1002/14651858.CD012656.pub2

22. Taylor WRJ, Thriemer $\mathrm{K}$, von Seidlein L, Yuentrakul P, Assawariyathipat T, Assefa A, et al. Short-course primaquine for the radical cure of Plasmodium vivax malaria: a multicentre, randomised, placebo-controlled non-inferiority trial. Lancet. 2019;394(10202):929-38. doi: 10.1016/S0140-6736(19)31285-1

23. Sokol AM, Sydorchuk AS, Bohachyk NA, Venhlovs'ka YaV. Maliariia vivax na Bukovyni: klinichnyi vypadok bezkontrol'noho samolikuvannia [Vivax malaria in Bukovina: a clinical case of uncontrolled self-medication]. ScienceRise: Medical Science. 2017;(7):30-3. doi: 10.15587/2519-4798.2017.107918 (in Ukrainian).

24. Trihleb VI, Karimov IZ, Kondratyuk VV, Pavlovskaya MA, Artemov AE, Homyakova AYu, ta in. Analiz vazhkykh vypadkiv tropichnoi maliarii [Analysis of severe cases of malaria falciparum]. Family medicine. 2013;(1):135-9. (in Ukrainian).

25. Graves PM, Gelband H, Garner P. Primaquine for reducing Plasmodium falciparum transmission. Cochrane Database Syst Rev [Internet]. 2012[cited 2020 Oct 16];(9):CD008152. Available from: https:/www.cochranelibrary.com/cdsr/ doi/10.1002/14651858.CD008152.pub2/epdf/full doi: 10.1002/14651858.CD008152.pub2

\section{Відомості про авторів:}

Сидорчук А.С. - доктор філософії, доцент кафедри внутрішньої медицини та інфекційних хвороб Вищого державного навчального закладу України «Буковинський державний медичний університет», м. Чернівці, Україна. ORCID ID: https://orcid.org/0000-0002-1959-6612

Москалюк В.Д. - д.мед.н., професор, професор кафедри внутрішньої медицини та інфекційних хвороб Вищого державного навчального закладу України «Буковинський державний медичний університет», м. Чернівці, Україна. ORCID ID: https://orcid.org/0000-0001-6206-1210

\section{Сведения об авторах:}

Сидорчук А.С. - доктор философии, доцент, доцент кафедры внутренней медицины и инфекционных болезней Высшего государственного учебного заведения Украины «Буковинский государственный медицинский университет», г. Черновцы, Украина.

Москалюк В.Д. - Д.мед.н., профессор, профессор кафедры внутренней медицины и инфекционных болезней Высшего государственного учебного заведения Украины «Буковинский государственный медицинский университет», г. Черновцы, Украина.

\section{Information about authors:}

Aniuta Sydorchuk - doctor of philosophy, associate professor, associate professor of department of internal medicine and infectious diseases Higher state educational establishment of Ukraine "Bukovinian state medical university", Chernivtsi, Ukraine.

ORCID ID: https://orcid.org/0000-0002-1959-6612

Vasyl Moskaliuk - doctor of medicine, professor, professor of department of internal medicine and infectious diseases Higher state educational establishment of Ukraine "Bukovinian state medical university", Chernivtsi, Ukraine.

ORCID ID: https://orcid.org/0000-0001-6206-1210

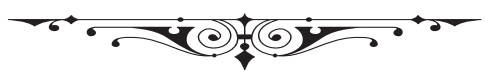

